\title{
Audio průvodce v muzejní praxi ${ }^{1}$
}

Michaela Smidová

\section{Audioguide in Museum Practice}

Abstract: The topic of the paper is the use of audioguides in the contemporary museum practice. It includes an overview of the development of the audioguides and their use since their implementation, the Czech and world research and case studies as well as the guidance through the process of creating an audioguide. It also deals with the audioguides designed for the visually impaired visitors and their specific requirements.

Keywords: audioguide, visitor experience, museum marketing, visually impaired visitors

Od dob vzniku prvních veřejnosti př́stupných muzeí se etablovala představa muzea jako objektivní odborné instituce s primárním cílem shromaždovat významné předměty a prezentovat je skupině návštěvníků limitované svým socioekonomickým postavením nebo úrovní vzdělání. Tento koncept byl ale kritizován již od začátku 19. století. ${ }^{2} \mathrm{~V}$ rámci rozvoje tzv. nové muzeologie ${ }^{3}$ od 80 . let minulého století se vedle sbírkotvorné činnosti muzeí začíná pořád víc zdůrazňovat společenská role muzeí, jejich interdisciplinární aspekt a potřeba nových způsobů komunikace s návštěvníkem. Kromě sbírkotvorné činnosti a zaměření na autentické předměty ("object-centered approach“) se do popředí dostává zároveň i požadavek zasadit exponáty do kontextu, který je srozumitelný a poutavý pro co nejširší skupinu návštěvníků („visitor centered" nebo ,idea-centered approach“). ${ }^{4}$ Poslední dekády tak muzea stojí před nelehkým úkolem nejen představit sbírkové předměty prostřednictvím svých výstav a expozic, ale zároveň návštěvníky všech věkových a sociálních skupin zaujmout, pobavit, efektivně zprostředkovat poznání a pružně reagovat na jejich očekávání, požadavky a celkově společenské změny. Mezi tyto požadavky patř́ především možnost přizpůsobit si prohlídku individuálním potřebám nebo zájmům.

$\mathrm{V}$ první polovině 20. století byla muzea ještě považována za primárně sbírkotvorné instituce a práci s návštěvníkem se věnovala jen minimální pozornost. $V$ této době se ale již začínají objevovat nové př́stupy, které záhy nabývají na popularitě. V roce 1903 byly představeny první interaktivní prohlídky v mnichovském Deutsches Museum. ${ }^{5}$ Rychle postupující vývoj v oblasti elektrotechniky a komunikačních technologií po druhé světové válce znamená revoluci $\mathrm{v}$ mnoha oblastech lidského života, kulturní instituce nevyjímaje. $\mathrm{V}$ roce 1952 přišel ředitel Městského muzea v Amsterdamu Willem Sandberg $\mathrm{s}$ návrhem nahrát komentáře k jednotlivým exponátům na magnetickou pásku a prenášet je rádiovým signálem do příručních přijímačù opatřených sluchátky. Z pohledu návštěvníků to byl zcela přelomový vynález. Poprvé jim byla nabídnuta možnost individuálně uzpůsobené prohlídky, během které mohou ovlivnit její tempo, délku trvání nebo počet shlédnutých objektů. ${ }^{6}$ V Československu byl první automatický průvodce uveden do provozu již $\mathrm{v}$ roce 1958 na výstavě Pravěk Československa v Národním muzeu. Tento průvodce dokonce efektivně spojoval řadu tehdejších technologických vymožeností - výklad nahraný na magnetofonových páskách byl pomocí reléové automatiky propojen se spuštěním osvětlování předmětného exponátu a mechanickým zařízením, které umožňovalo např́íklad otáčet vitrínou. ${ }^{7}$ Během technického boomu 60. let se príiruční audio průvodce stal neoddělitelnou součástí všech větších západoevropských
1 Předložená práce vznikla za finanční podpory Ministerstva kultury $v$ rámci institucionálního dlouhodobého koncepčního rozvoje výzkumné organizace Národní muzeum (DKRVO 2019-2023/26.I.C, 00023272).

2 WAIDACHER, Friedrich. Príručka všeobecnej muzeológie. Bratislava: Slovenské národné múzeum, 1999, s. 51. 3 Více $k$ tématu nové muzeologie napr. VERGO, Peter (ed.). New Museology. London: Reaktion Books, 1989.

4 VELÁZQUEZ MARRONI, Cynthia. Beyond the „object-oriented vs. visitorlidea-oriented museum" divide: the value of objects for museum experiences. In Museologica Brunensia, roč. 6, č. 1 (2017), S. 13.

5 WAIDACHER, Friedrich. Príručka všeobecnej muzeológie. Bratislava: Slovenské národné múzeum, 1999, s. 66. 6 TALLON, Loic; WALKER, Kevin. Digital Technologies and the Museum Experience: Handheld Guides and Other Media. Plymouth: AltaMira Press, 2008, s. $x$. 7 KOCICHOVÁ, Ivana. Výstava Pravěk Československa (1958) v Národním muzeu: Světlo, zvuk a pohyb v roli průvodce návštěvníka. In. Muzeum: Muzejní a vlastivědná práce, roč. 53, č. 2 (2015), s. 12.

Mgr. Michaela Smidová Centrum pro prezentaci kulturního dědictví Národní muzeum michaela.smidova@nm.cz 
8 DOUŠA, Pavel. Text ve výstavě. In Múzeum, roč. 54, č. 1 (2008), s. 11.

9 SERREL, Beverly. Exhibit Labels. An Interpretive Approach. Lanham: Rowman \& Littlefield, 2015, s. 19. 10 AMBROSE, Timothy; PAINE, Crispin. Museum Basics: The International Handbook. London, New York: Routledge, 2018, s. 164. 11 DOUŠA, Pavel. Text ve výstavě. In Múzeum, roč. 54, č. 1 (2008), s. 12.

12 KUBUं, Nad'a, KADLEC, Miloš, FAMĚROVÁ, Dagmar, HOLUB, Jiří, WAGNER, Peter. Metodika průvodcovské činnosti na hradech, zámcích a dalších zprístupněných památkách. Praha: Národní památkový ústav, 2014, s. 46. 13 MANNION, Shelley, SABIESCU, Amalia, ROBINSON, William. An audio state of mind. Understanding behaviour around audio guides and visitor media [online]. MW2015: Museums and the Web 2015 [cit. 25.6.2021].

Dostupné z: https://mw2015. museumsandtheweb.com/ paperlan-audio-state-of-mind-understanding-behviour-around-audio-guides-and-visitor-medial. a severoamerických muzeí a galerií. V současnosti již audio průvodci mají různé podoby, od tradičních přijímačù, přes tablety, mobilní aplikace nebo QR kódy. Jak ale zjistit, která $z$ nich je nejvhodnější pro návštěvníky a instituce zároveň? $\mathrm{A}$ jsou audio průvodci $\mathrm{v}$ době snadno přístupných informací a nových rolí určených muzeím vůbec zapotřebí?

Fenoménu audio průvodců se věnuje jen málo metodik a výzkumů. I přesto se rozhodně nedá říct, že by se jednalo o okrajové téma. Se zařízeními audio průvodce je možné setkat se v muzeí, galeriích nebo jiných výstavních prostorách všech velikostí, zaměření a cílových skupin. Samotný audio průvodce je přitom unikátní svou komplexností přípravy, očekávaným dlouhodobým provozem a využitím média předem nahraného zvuku. Od audio průvodce se očekává plnění řady funkcí: sdělení adekvátních informací o výstavě nebo instituci, poutavost a atraktivnost pro co možná nejširší okruh návštěvníků, dlouhodobé udržení posluchačovy pozornosti, uživatelská přístupnost, včetně zpřístupnění instituce zahraničním návštěvníkům a návštěvníkům se specifickými potřebami. Stejně jako v dalších aspektech provozu muzea, i zde je nezbytné navíc sledovat aktuální trendy. Dostupné technologie se rychle vyvíjí, v oblasti muzejní prezentace se do popředí dostává interaktivita, přístupnost a možnost individuálně přizpůsobit svou návštěvu. I v případě tvorby a aktualizace audio průvodců je tedy nevyhnutelnou částí procesu komunikace odborníků na všechny aspekty muzejního provozu, stejně jako efektivně vyhodnocená zpětná vazba od návštěvníků.

\section{Poslouchat nebo neposlouchat?}

Ačkoliv primárním médiem sdělení ve výstavě jsou objekty samotné, architektura výstavy nebo grafické prvky, doprovodný text hraje nezastupitelnou roli. ${ }^{8}$ Stranou propagačních tiskových materiálů a výstavních katalogů se návštěvník muzea nebo galerie nejčastěji dostává do kontaktu s psaným textem ve formě popisku.
Popisek, umístěn zpravidla v bezprostřední blízkosti předmětu, má tradičně za úkol sdělit návštěvníkovi základní nebo relevantní faktografické údaje o objektu. V posledních dekádách se považuje za důležité, aby popisek nesl i sdělení o kontextu umístění předmětu ve výstavě ve vztahu k výstavnímu plánu a dalším exponátům, a také důvod, proč by se návštěvník měl o daný předmět zajímat. ${ }^{9}$ Na druhou stranu je prokázáno, že průměrný návštěvník přečte jen přibližně jednu desetinu celkového objemu textu, který je ve výstavě nabídnut. ${ }^{10}$ Důvody se různí: text je nezřídka umístován ve výši očí a je tedy nutno u četby nepohodlně stát, text je př́lišs obsáhlý nebo nesrozumitelný, pozornost je od četby odváděna vizuálními vjemy, nebo pro návštěvníka není přijímání informací četbou z různých důvodů možné nebo komfortní. I u popisů připravených s maximálním ohledem na návštěvníka však není možné ovlivnit jeho zájem nebo preference. Obecně je ale přijímáno, že rozsah textu ve výstavě by měl splňovat požadavek na svůj informační charakter, ale zároveň musí být limitován $\mathrm{v}$ závislosti od možností běžného návštěvníka udržet pozornost a zájmu návštěvníka o přečtení popisku. Moderní standardy uvádí maximální doporučený rozsah jednoho samostatného textového pole 100 až 150 slov na panel, 30 až 50 slov na popis exponátu. ${ }^{11}$ Ačkoliv text ve výstavě představuje efektivní formu sdělení informací, je nevyhnutné kromě jeho pečlivé přípravy nabídnout i alternativu.

Od začátku tohoto tisíciletí se již i v českých muzeích, galeriích a památkových objektech do popředí dostává využití audio průvodce jako doplňkové formy prezentace výkladu průvodce. ${ }^{12}$ Principem audio průvodce je jednoduše zprostředkování informací návštěvníkovi prostřednictvím elektronického nebo digitálního zařízení. V současnosti jsou již relativně vyspělé technologie každodenní součástí života. Pro většinu návštěvníků nepředstavuje jejich ovládání zásadní problém. Právě naopak, mají potenciál přiblížit a zatraktivnit muzea i pro nové cílové skupiny, zejména pro mladé lidi. Na druhou 
stranu si řada lidí neztotožňuje návštěvu výstavy s použitím přehrávacího zařízení, mají nedostatečné povědomí o možnostech a charakteru těchto průvodců, nebo je nepovažuje za dostatečně důvěryhodné. ${ }^{13}$ Proč tedy věnovat čas a finance tvorbě audio průvodce?

Důležitým rozdílem, který návštěvník vnímá mezi komentovanou prohlídkou a audio průvodcem, je pocit možnosti volby zastavení a času stráveného u jednotlivých prvků výstavy nebo expozice, pocit samostatnosti a širšího prostoru pro pohyb ve výstavních prostorách. Zároveň ale audio průvodce nabízí rámcovou strukturu prohlídky, jasně daný směr odkazující na vzájemně související části výstavy nebo výběr nejpozoruhodnějších exponátů. Empirické výzkumy prokazují, že tyto faktory zásadně pozitivně ovlivňují celkový dojem z návštěvy muzea. ${ }^{14}$ Přítomnost audio průvodce výrazně mění i celkový dojem z výstavy - díky dostupnosti komentáře může být redukován doprovodný text ve výstavě, co může návštěvníka motivovat k zvýšenému zájmu o kontext vystaveného předmětu a samotná výstava působí přístupněji. ${ }^{15}$ Kromě toho mají tvůrci audio průvodců možnost pracovat s komplexní, předem určenou strategií, včetně specifických formulací komentářù, tónu hlasu nebo cíleného navozování pocitů u posluchače, nemluvě již o větší variabilitě pro návštěvníky se specifickými potřebami. Na druhou stranu není pochyb o tom, že i komentované prohlídky s průvodcem mají svá nesporná pozitiva a v současnosti je $\mathrm{k}$ dispozici řada metodik $\mathrm{k}$ jejich kvalitní př́ipravě a realizaci. ${ }^{16}$ Pro návštěvníka je pak důležitá možnost volby - mezi komentovanou prohlídkou nebo audio průvodcem, nebo mezi jejich různými formami a alternativami.

Specifikem audio průvodců je především jejich dopad na sociální aspekt návštěvy muzea nebo galerie. Zvuk je během komentované prohlídky vítaným doplňkem a rozšírením vizuálního vjemu. Audio průvodce tento prožitek ale silně individualizuje, a to i v případě, že se jedná o nahrávku bez možnosti individuální modifikace tempa nebo volby jednotlivých zastavení.
Značná část návštěvníků do muzea přichází v doprovodu další osoby nebo osob, ale, jak uvádí Margot Wallace, audio průvodce „obklopuje posluchače v jejich soukromé bublině koncentrace."17 Zdá se pak namístě obava kurátorů, že využívání individuálních audio průvodců bude zabraňovat diskusím nad významem vystavených díl, výrazně se zkrátí čas strávený ve výstavních prostorách a celkový dojem z výstavy nebo expozice bude utlumen. Jak ale dokazují výzkumy z posledních let, návštěvníci neočekávají, že diskuse nebo interakce obecně budou probíhat přímo ve výstavě nebo expozici. Naopak, institucemi samotnými je často nedoceněna role odpočinkových prostorů, kavárny nebo muzejního obchodu, kde se uskutečňuje společenský aspekt návštěvy. ${ }^{18}$ I přes běžná očekávání absentuje sociální interakce i u komentovaných prohlídek pod vedením kvalifikovaného průvodce. Možnost klást dotazy nebo diskutovat využívá jen zlomek jejich účastníků, neznámí účastníci prohlídky mezi sebou zpravidla neinteragují. ${ }^{19}$ Snahy průvodce o obousměrnou komunikaci, která je doporučována řadou metodik, mají jen těžko předvídatelný výsledek a závisí od charakteru dané skupiny návštěvníků.

Je pochopitelně nutné brát v potaz, že část návštěvníků nemá zájem o strukturovanou prohlídku nebo informace navíc $\mathrm{k}$ těm, které jsou $\mathrm{k}$ dispozici ve formě výstavního textu. Pro ty, kteří tvoří potenciální cílovou skupinu budoucího audio průvodce, je zásadní nejen jeho samotná nabídka, ale také forma, obsah nebo jeho propagace. Jaké jsou tedy možnosti a metodická doporučení teoretických odborníků i profesionálů z praxe na vytvoření audio průvodce zohledňujícího požadavky veřejnosti i instituce?

\section{Muzeum v dlani: Technologie audio průvodců}

První audio průvodci, uvedeni do provozu ve výše zmíněném muzeu Stedelijk v roce 1952, se i přes technologická omezení své doby ve svém konceptu jen málo lišily od svých protějšků, se kterými se
14 WALLACE, Margot. Museum Branding. How to Create and Maintain Image, Loyalty, and Support. London: Rowman \& Littlefield, 2016, s. 23.

15 MARQUES, Diana,

COSTELLO, Robert. Reinventing Object Experiences with Technology. In. Exhibition, roč. 37, č. 1 (jaro 2018), s. 81.

16 Např. WALLACE, Margot. Writing for Museums; LEVY, Barbara A., LLOYD, Sandra M., SCHREIBER, Susan P. Great Tours!: Thematic Tours and Guide Training for Historic Sites. Lanham: Altamira Press, 2001.

17 WALLACE, Margot. Writing for Museums. Lanham: Rowman \& Littlefield, 2014, S. 2.

18 TALLON, Loic; WALKER, Kevin. Digital Technologies and the Museum Experience: Handheld Guides and Other Media. Plymouth: AltaMira Press, 2008, s. 66.

19 Výsledek z průzkumů uskutečňovaných $v$ newyorských muzeích Whitney Museum of American Art, Metropolitan Museum of Art, The Jewish Museum. TALLON, Loic; WALKER, Kevin. Digital Technologies and the Museum Experience: Handheld Guides and Other Media, s. 66. 


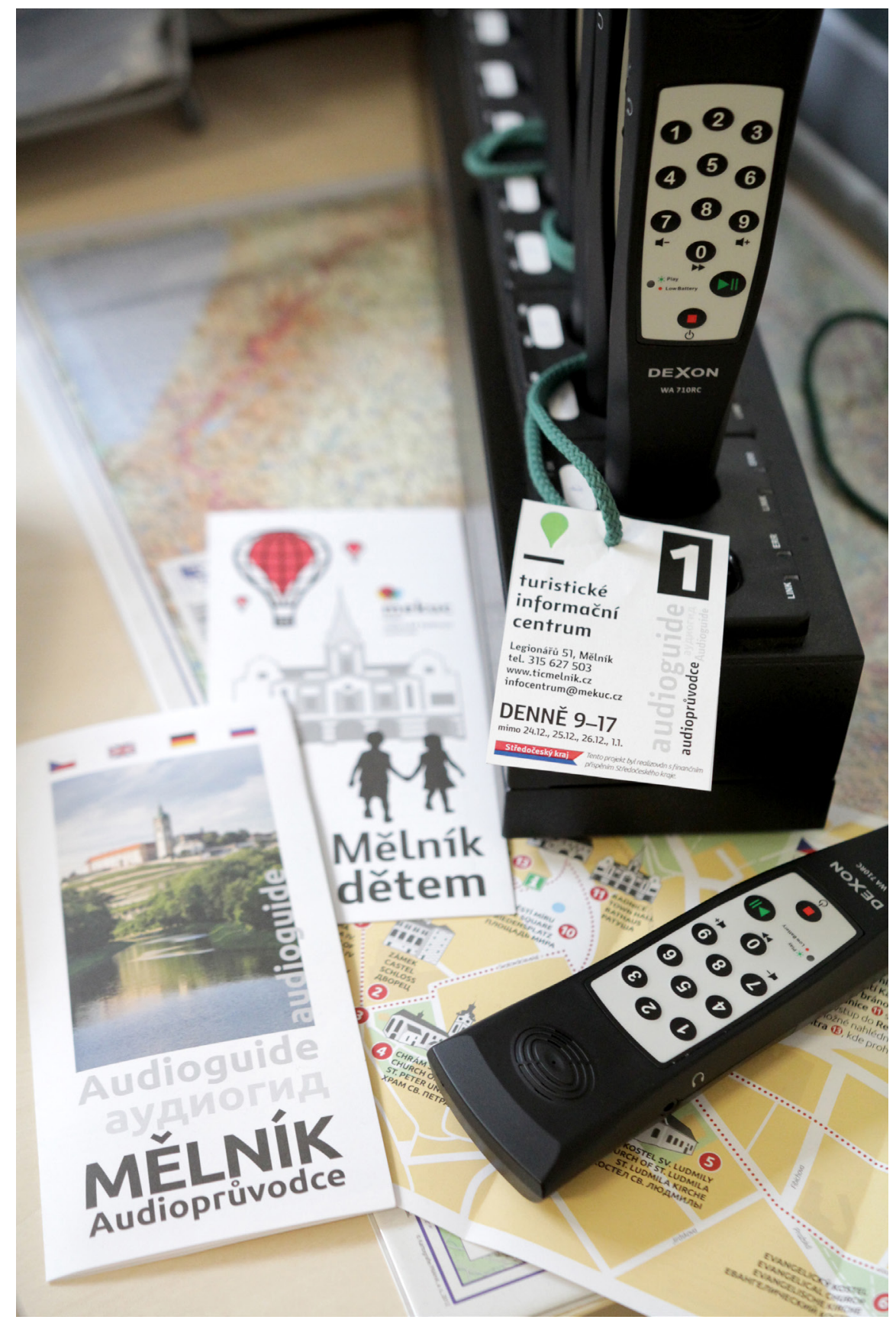

Příklad príručního zařízení s nahrávkou audio prüvodce po městě Mělník ve dvou variantách trasy, foto: archiv TIC Mělník

20 TALLON, LOIC; WALKER, Kevin. Digital Technologies and the Museum Experience: Handheld Guides and Other Media, s. xiii-xiv. můžeme dnes setkat v muzeích nebo památkových objektech. Jednalo se o přenosná zařizení vybavená sluchátky, která si návštěvník vyzvedl u vstupu do muzea. Do těchto zařízení byl pak rádiovým signálem přenášen dopředu nahrán komentář k expozici. Od 70. let byla pak nahrávka již přímou součástí zařízení, co umožňovalo přestávky, přeskočení nebo opakování pasáží podle přání uživatele. Až do rozšíření internetové sítě tvořila tato forma audio průvodců nejrozšířenější technologický prvek návštěvy muzea. ${ }^{20}$ $\mathrm{V}$ současnosti nejčastějším typem audio průvodce $\mathrm{v}$ našich muzeích je příruční zařizení s nahrávkou. Řada návštěvníků, zejména starší generace, je tak již na tuto technologii zvyklá a u vstupu ji očekává. Od 50. let se výrazně změnila forma i obsah příručních audio průvodců. Souvislý výklad je dnes již standardně nahrazen jednotlivými nahrávkami, které si uživatel navolí podle čísel nebo jiných označení umístěných v expozici nebo plánu výstavních prostor. Návštěvníkovi je tedy nabídnuta možnost jednotlivé nahrávky poslouchat v jiném než doporučeném poradí, kdykoliv je pozastavit nebo ukončit. Podle výzkumu více než 80 \% respondentů vyjádřilo zájem právě o tuto variantu. K dispozici může být nabídnuta i dvojí verze nahrávky - kratší se základními informacemi k předmětu nebo části výstavy, a delší s rozšiřujícím komentářem, který obsahuje širší kontext nebo odkazuje na navazující exponát. Trendem je také snaha o zatraktivnění tohoto typu audio průvodce za pomoci technologicky inovativních přístrojů obsahujících například obrazovky na způsob tabletu nebo nabídkou řady jazykových mutací komentářo nebo tematicky zaměřených prohlídkových tras. Př́ruční zařízení na rádiový přenos zvuku může být využito i u komentovaných prohlídek s průvodcem, zejména $\mathrm{v}$ případě prostorově rozsáhlých výstavních prostor nebo památkových objektů v exteriéru.

Ačkoliv mají příruční audio průvodci za sebou historii dlouhou desetiletí, pro současná muzea jejich zrrízení a provoz mohou pořád představovat výzvu. Cena jednotlivých zařízení se pohybuje řádově v tisících českých korun, další náklady v průběhu jejich používání představuje nezbytná pravidelná údržba, nabíjení, opravy nebo náhrada vyřazených zařízení. Tyto náklady může zčásti kompenzovat poplatek za využití služeb audio průvodce nebo vratná záloha na zařízení, návštěvník ale často očekává tuto službu již zahrnutou v ceně vstupného. Pro zabezpečení plné návštěvnické spokojenosti je nezbytné zajistit nejen to, aby byl personál pultu se zařízeními plně informován o technických specifikách př́istrojůa, schopen provést základní nastavení a podat srozumitelný návod návštěvníkům, ale určitou úrovní těchto znalostí 
a dovedností by měli disponovat i všichni pracovníci dozoru expozic, aby dokázali tápajícím návštěvníkům pomoct nebo je správně nasměrovat. ${ }^{21}$ Vzdělávání pracovníků v první linii by mělo pochopitelně proběhnout i v souvislosti s jakoukoliv aktualizací technického vybavení nebo změnou standardní trasy audio průvodce. Jako konkurence audio průvodcům ve formě př́ručních zařízení se zejména v posledním desetiletí etablují mobilní aplikace. Masové rozšíření chytrých mobilních telefonů a veřejně přístupné Wi-Fi sítě, stejně jako požadavek zejména mladých návštěvníků na nové standardy technologické úrovně způsobily, že řada světových muzeí již považuje systém př́strojů $\mathrm{k}$ zapůjčení i samotného audio průvodce za přežitek. Výrazný př́klon $\mathrm{k}$ využití vlastních př́strojů návštěvníků místo dosavadního systému zapůjčených přehrávačủ byl zaznamenán $\mathrm{v}$ souvislosti s bezpečnostními opatřeními během pandemie viru COVID 19.22 Mobilní aplikace bezesporu představuje rozšíření možností, které jsou návštěvníkovi k dispozici. Kromě audio výkladu, který může uživatel libovolně modifikovat dle přání, mohou aplikace nabízet nespočet variant komentáŕe, ale i textový obsah, vizuální nebo audiovizuální doplňkový materiál, interaktivní prvky, nebo plán muzejní budovy využívající GPS údaje o poloze. Populární je v posledních letech také využití technologie AR (augmented reality). Ta umožňuje např́klad vizualizaci původního stavu sbírkových předmětů nebo památkových objektů, nebo rozpohybování statických instalací na obrazovce mobilního telefonu nebo tabletu. ${ }^{23}$

Jak prokazují empirické výzkumy z provozu těchto mobilních aplikací ve světových muzeích, jejich využívání výrazně zvýší čas strávený $\mathrm{v}$ expozici nebo výstavě. Pozorování v Smithsonian's National Museum of Natural History prokazují, že po uvedení mobilní aplikace s řadou dostupných funkcí vzrostla průměrná délka pobytu návštěvníka $\mathrm{v}$ do té doby málo populární expozici z konce 60 . let z původních 1 minuty 34 sekund (pouze $26 \%$ návštěvníků $\mathrm{v}$ expozici setrvalo déle než
3 minuty) na 14 minut. ${ }^{24}$ Další výhodou je možnost cílit na mladého návštěvníka - zcela jednoznačná preference pro formát mobilní aplikace je u věkové skupiny 7-25 let, zatímco se stoupajícím věkem se zvyšuje upřednostňování kombinace audio průvodce $\mathrm{v}$ samostatném př́stroji a obsáhlejších doprovodních textů a popisků ve výstavě. Mladí návštěvníci také mimořádně oceňují rozšířené možnosti aplikace, jako jsou odkazy na další webové stránky, interaktivní funkce (např. minihry, fotografické filtry), multimediální charakter, a v neposlední řadě propojenost se sociálními sítěmi. Právě možnosti využití i mimo výstavní prostory, at už ve sdíleném virtuálním prostoru nebo plně off-line, je velkým př́nosem - její uživatel se tak může vrátit $k$ obsahu výstavy nebo expozice, upevnit si nabyté vědomosti a opětovně prožít emoce $\mathrm{z}$ návštěvy, co ho má potenciál motivovat $k$ návratu nebo doporučení návštěvy objektu. Motivační funkce off-line aplikace může mít dopad i na zájemce, co se rozhodují návštěvu teprve podniknout. Populární variantou mobilních aplikací je př́stup $\mathrm{k}$ audio průvodci nebo doplňkovým informacím a aktivitám přes $Q R$ kódy. Pro návštěvníky je to výhodné $\mathrm{v}$ tom, že funkcí čtení QR kódů disponují i starší modely chytrých telefonů a obsah není stahován př́mo do zařízení. Pozitivem využití QR kódů je také nižší cena oproti vývoji aplikace, co je zcela zásadní zejména pro menší muzea. Také to umožňuje vytvoření vícero tras prohlídky nebo modifikaci formy nabízeného obsahu pro návštěvníky se specifickými potřebami (např. př́stup k video komentáŕi ve znakovém jazyce). $\mathrm{V}$ posledních letech se etablují nové alternativy $k$ technologii $Q R$, které sebou nenesou její omezení ( $\mathrm{v}$ šeru nebo dokonce pološeru se kód nezřídka nenačítá, co vylučuje použití technologie u vystavených sbírkových předmětů citlivých na světlo). Pro přístup pro širší veřejnost se rozšírílo používání technologie NFC (Near-Field Communications), která pracuje na principu přenosu dat na krátké vzdálenosti a je již zabudována ve valné většině současných chytrých telefonů. ${ }^{25}$ Ještě donedávna se zdálo, že technologie
21 MANN, Laura, TUNG, Grace. A new look at an old friend: Reevaluating the Met's audio-guide service [online]. MW2015: Museums and the Web 2015 [cit. 25.6.2021]. Dostupné z: https://mw2015. museumsandtheweb.com/ paper/a-new-look-at-an-old-friend-re-evaluating-the-mets-audio-guide-servicel.

22 What's next for Museum Audio Guides. Research Report / September 2020 [online]. Dostupné z: https://www. museumnext.com/wp-content/ uploads/2020/09/museummate_research_report-1.pdf. 23 Napr. COATES, Charlotte. How Museums are using Augmented Reality. In. MuseumNext, 17. září 2020 [cit. 2021-01-20]. Dostupné z: https://www.museumnext.com/ article/how-museums-are-using-augmented-realityl. 24 MARQUES, Diana, COSTELLO, Robert. Reinventing Object Experiences with Technology.s. 79. 25 CHARR, Manuel. What Can Near-Field Communications Do For Museums? In. MuseumNext, 13. zárí 2019 [cit. 2021-01-20]. Dostupné z: https://www.museumnext.com/ article/what-can-near-field-communications-do-for-museums/. 
26 Např. HEIMBROCK, Anna. Corona-proofing museum interactives. In. MuseumNext, 10. srpen 2020 [cit. 2021-0120]. Dostupné z: https://www. museumnext.com/article/ corona-proofing-museum-interactives/.

27 Karty s OR kódy nabízí napríklad společnost Nubart, www.nubart.eu [cit. 2021-01-20].

28 KESNER, Ladislav. Marketing a management muzeí a památek. Praha: Grada, 2005, s. 210.

29 Podle průzkumu príibližně 10-35\% návštěvníků preferuje lineární následování všech nabídnutých zastavení $i$ u audio průvodce s volnou trasou. MANNION, Shelley, SABIESCU, Amalia, ROBINSON, William. An audio state of mind. Understanding behaviour around audio guides and visitor media.
QR kódů je definitivně za zenitem, ale přísná preventivní opatření během pandemie koronaviru ji opět vrátila do světových muzeí. ${ }^{26}$ Marketingově zajímavou variantou je umístění QR kódu na kartu, kterou obdrží zájemce o audio průvodce, nebo přímo na vstupence. Kromě přístupu ve výstavě nebo mimo prostor muzea tak návštěvník obdrží zároveň i suvenýr, který si může vzít s sebou. ${ }^{27}$

Zvolení technologie pro audio průvodce je zcela zásadním krokem, který ovlivňuje nejen výši investice muzea do technologie, míru spolupráce $\mathrm{s}$ dalšími odborníky a subjekty mimo muzeum samotné a dispozici budoucích výstav a expozic, ale může se také projevit na věkovém složení návštěvníků, propagaci instituce nejen na sociálních sítích nebo přístupnosti pro návštěvníky se speciálními potřebami. V neposlední řadě je funkční, uživatelsky př́istupný audio průvodce at' už samotný, nebo doprovázen dalšími funkcemi - významným faktorem v celkové spokojenosti návštěvníka. Důležité je proto sledovat trendy v oblasti technologií a jejich využití v muzejnictví pro pozitivní zážitek co největší skupiny návštěvníků.

\section{Od plánování k návštěvníkovi}

At’ si už muzeum nebo galerie zvolí jakoukoliv z technologických variant realizace audio průvodce, je zcela nezbytné, aby samotné realizaci předcházel pečlivý proces prípravy a tvorby jeho obsahu. Na rozdíl od lektorské komentované prohlídky je audio průvodce komplexním, reprezentativním výstupem, od kterého se zejména v případě expozic a dlouhodobých výstav očekává, že bude svou funkci plnit v perspektivě několik let. Na jeho tvorbě by se ideálně měla podílet řada odborníků od kurátorů, produkčních, muzejních edukátorů, PR a marketingu až po IT specialisty. Na rozdíl od např́klad vědeckého katalogu se přípravy průvodce nemusí nevyhnutelně účastnit odborníci na téma výstavy, kteří nezřídka spolupracují externě a nemusí být vždy $\mathrm{k}$ dispozici muzeu. ${ }^{28}$ Základem je ovšem jednotná koncepce a znalost potřeb a preferencí návštěvníků.

\section{Typ prohlídky}

Muzeum si u tvorby audio průvodce může zvolit jednu z dvou základních konceptuálních variant:

a) Lineární trasa - tradiční model provede návštěvníka dopředu vytyčenou linkou s minimální možností individuální modifikace. Předností této varianty je vysoká míra kontroly tvůrců průvodce nad představením zvolených předmětů ve vzájemném kontextu i kontextu celé instalace, stejně jako nad komunikací celkového cílového sdělení. Návštěvník může pozitivně hodnotit, že délka prohlídky je předem známá. Jako př́nos může být vnímána i absence nutnosti vlastní iniciativy ze strany návštěvníka, zejména u zájemců s minimálním předchozím povědomím o tématu. $V$ posledních letech je trendem nabízet hned několik variant lineárních prohlídkových tras pro různé skupiny návštěvníků na základě výchozích znalostí nebo zájmu, věku, tematického zaměření nebo specifických potřeb.

b) Volná trasa - návštěvníkovi je dána $\mathrm{k}$ dispozici databáze nahrávek $\mathrm{k}$ jednotlivým zastavením (objektům), často s doporučeným pořadím, kterého se ale není nutné držet. Návštěvník má možnost přizpůsobit prohlídku svým potřebám, preferencím a časovým možnostem. Populární je nabídnutí dvou variant nahrávky $\mathrm{k}$ danému zastavení - kratší pro základní informace a delší, obsahující rozšiřující kontext nebo odkazy na související části výstavy. Na druhou stranu z pohledu muzea je tato varianta náročnější na přípravu. Pro návštěvníka nemusí být zřejmý kontext výstavy nebo expozice, cílové sdělení instalace je náročnější na komunikaci. Je potřeba také počítat s rizikem, že návštěvník opomene klíčové exponáty, což ovlivní jeho dojem z výstavy. Sdělení v nahrávce by mělo navíc relativně rychle uvést posluchače do kontextu předmětu a zároveň upoutat jeho pozornost, $\mathrm{v}$ opačném případě může posluchač využít možnost nahrávku přepnout. 
I přes tyto výzvy je formát volné trasy čím dál populárnější zejména pro svou vysokou variabilitu a pocit svobodného rozhodování, který vyvolává u návštěvníka. ${ }^{29}$

\section{Klíčové slovo}

Margot Wallace jako další krok, který by $\mathrm{v}$ procesu produkce audio průvodce měl předcházet samotné tvorbě scénáře, doporučuje zvolení klíčového slova. Klíčové slovo by mělo souviset s tématem výstavy nebo expozice a vytvářet základní rámec prezentovaného narativu. Kromě toho, že text průvodce pak působí celistvě, tak sledování klíčového slova napomáhá udržet pozornost posluchače a úspěšně komunikovat autorský záměr výstavy. Wallace doporučuje $\mathrm{k}$ tomuto účelu zvolit srozumitelný, relativně obecný pojem - jako příklad uvádí klíčové slovo "umělec" výstavy v Institutu umění v Chicagu - který návštěvník snadno identifikuje a zároveň je možné ho vztáhnout $k$ většině vystavených předmětů. ${ }^{30}$

\section{Výběr trasy a předmětů}

Stěžejním krokem v procesu tvorby audio průvodce je výběr trasy nebo vystavených předmětů, kterým budou věnovány nahrávky. Je pochopitelně zcela nemožné obsáhnout všechno, co nabízí výstava nebo expozice. Pro návštěvníky i kurátory je ale žádoucí, aby průvodce zahrnoval, co možná nejvíc z př́stupných prostor a představil muzeum nebo jeho část (výstavu, expozici, instalaci, historické prostory) komplexně a zároveň se soustředěním pozornosti na nejdůležitější části.

U výběru předmětů, kterým bude věnován samostatný komentář $\mathrm{v}$ audio průvodci, se lze ř́dit hned několika možnými kritérii. Zvolené předměty by se měly alespoň okrajově týkat klíčového slova nebo tématu trasy. Celkově předměty vystavené $\mathrm{v}$ expozici je možné rozdělit do čtyř skupin, přičemž je vhodné, aby byla každá $\mathrm{z}$ nich zastoupena a během výkladu došlo k pravidelnému střídání:

1. předměty vysoké historické nebo umělecké hodnoty, highlights výstavy či expozice, které jsou návště- vníkovi prezentovány jako exkluzivní a neopomenutelné

2. předměty, které jsou pro téma nebo záměr expozice stěžejní, ale jejich význam je většině návštěvníků zřejmý až po vysvětlení jejich kontextu

3. předměty, které nemusí mít nutně vysokou hodnotu, ale doplňující informaci je učiní pro návštěvníka atraktivními (zajímavý př́běh)

4. předměty, které nemají nutně vysokou uměleckou nebo historickou hodnotu, ale jsou pro návštěvníka $z$ jiného důvodu atraktivní (kuriozity, jsou známé z populární kultury) ${ }^{31}$

Kromě hlediska významu pro koncept výstavy a předání znalostí návštěvníkovi se ovšem tvưrci audio průvodce nevyhnutelně musí řídit i praktickými otázkami. Celková délka nahrávky průvodce (at̉ už v lineární formě, nebo součet délky jednotlivých základních nahrávek) by měla být přibližně totožná jako délka standardní komentované prohlídky. Tomu by se měl přizpůsobit i výběr jednotlivých zastavení. Doporučuje se zvolit kolem 20-40 \% ze všech exponátů.

Jednou z možností, jak se ujistit, že zvolené předměty jsou dostatečně pozoruhodné a vzbuzující zájem posluchačů, je přihlédnutí $\mathrm{k}$ názoru návštěvníka již v počátečních stádiích př́ípravy průvodce. At už formou dotazníkového šetření nebo pozorování skupin během komentované prohlídky s průvodcem, získané informace o preferencích návštěvníků a zejména jejich jednotlivých cílových skupin mohou být neocenitelnou pomocí. ${ }^{32}$

Kromě pozornosti posluchače je důležitým faktorem i fyzická dostupnost vybraných předmětů. Podobně jako u komentované prohlídky pod vedením průvodce, i zde by měly být preferovány předměty, které jsou instalovány v prostoru tak, aby byl kolem nich dostatek volného místa. Předpokládá se, že k těmto vybraným předmětům zamíŕi převážná většina uživatelů audio průvodce, vhodné jsou proto vitríny s možností náhledu $\mathrm{z}$ více než jedné strany (ideálně ze všech stran) umístěny ve větší než bezprostřední vzdálenosti
30 WALLACE, Margot. Writing for Museums, s. 2-3. 31 WALLACE, Margot. Writing for Museums, s. 3. 32 TALLON, Loic; WALKER, Kevin. Digital Technologies and the Museum Experience: Handheld Guides and Other Media, s. 76. 
33 BEST, Katie. Making Museum Tours Better: Understanding What a Guided Tour Really Is And What A Tour Guide Really Does. In Museum Management and Curatorship, roč. 27, č. 1 (únor 2012), s. 38-42.

34 HUGHES, Philip. Exhibition Design. Londýn: Laurence King, 2010, s. 152.

$35 U$ osob se zrakovým nebo sluchovým omezením je doba, během které je pro člověka možné plnohodnotně vnímat podněty, výrazně kratší, a to zejména u osob, u kterých došlo ke vzniku postižení později $v$ životè.

36 BORG, James. Umění přesvědčivé komunikace. Praha: Grada, 2007, s. 38. 37 WALLACE, Margot. Museum Branding. How to Create and Maintain Image, Loyalty, and Support, s. 28. od ostatních částí výstavy nebo expozice, zejména od dalších zastavení průvodce. Neméně významnou roli hraje také výše umístěných předmětů. Stejně jak během tvorby výstavy samotné, i během výběrů zastavení pro audio průvodce je nezbytné vzít v potaz, že mezi jeho uživateli budou i děti nebo lidi pohybující se na vozíku. Kromě dostatečně širokého manipulačního prostoru kolem je proto také podstatná výše umístění předmětu. Zejména u tvorby jediné univerzální trasy je nutné myslet na potřeby a omezení co největší části návštěvníků. Výzkumy dokazují, že během komentované prohlídky se pozornost, a s ní i oční kontakt s předmětem nebo pozice návštěvníka v prostoru, obrací na tu část díla, o které jsou ve výkladu zrovna sdělovány informace. ${ }^{33}$ Popisovat tak detaily v horní sekci velkorozměrného obrazu nebo na zadní straně předmětu, který není vystaven ve vitríně umožňující náhled ze všech stran, tak může být matoucí a nepohodlné pro návštěvníka a kontraproduktivní pro komunikaci autorského záměru výstavy a průvodce.

Kromě dostatečného přístupu k předmětu samotnému je pochopitelně stejně důležité zabezpečit dostupnost případného QR kódu, čísla nahrávky nebo jiného označení souvisejícího s použitím audio průvodce ve výstavních prostorech. Problematickými se tak mohou stát části výstavy nebo expozice s tlumeným osvětlením, s netradičním prostorovým řešením nebo nestandardně umístěnými popisky exponátů. ${ }^{34}$

\section{Scénář a nahrávka}

Základním krokem tvorby samotného scénáře audio průvodce je stanovení délky trasy nebo jednotlivých zastavení. Celkově by maximální délka prohlídky $\mathrm{s}$ audio průvodcem neměla být delší než délka běžné prohlídky bez něj, a to včetně času určeného pro pohyb po prostorách muzea z místa na místo. Celkově je potřeba počítat s horní hranicí 45 až 60 minut pro celou prohlídku, což je doba, během které je běžný člověk schopen udržovat pozornost. Pochopitelně tato doba se zkracuje v případě prohlídek určených dětem nebo osobám se specifickými potřebami. ${ }^{35}$ Obecně je potřeba pracovat s křivkou pozornosti. Soustředění na nabízené informace je největší na začátku poslechu, s ubíhajícím časem postupně klesá, ačkoliv se může následkem specifických podnětů opětovně krátkodobě zvýšit. ${ }^{36} \mathrm{U}$ plánování scénáře audio průvodce je možné toho využít například střídáním vysoce návštěvnicky atraktivních předmětů s těmi, které vyžadují určitou úroveň znalostí tématu nebo kontextu jejich významu. Toho by se měl tvưrčí tým držet i u jednotlivých zastavení. Na začátku by měly zaznít důležité, ale zároveň srozumitelné informace (úvodní informace „socha je stará 4500 let” je př́istupnější než varianta ",socha pochází ze 4. dynastie"), které pozornost návštěvníka upoutají a vyvolají v něm zájem dozvědět se o předmětu víc. Na druhou stranu, stejně jako v případě textu a popisků ve výstavě, je nezbytné najít rovnováhu mezi dostatečným informováním návštěvníka a jeho zahlcením přemírou informací. Mimořádně důležité je to zejména $u$ variantu audio průvodce s pevně stanoveným pořadím a délkou zastavení.

Casové rozpětí jednotlivých zastavení, se kterými se můžeme setkat $\mathrm{v}$ současných muzeích, se pohybuje mezi 30 sekundami až 3 minutami. Pro porovnání - délka běžné televizní reklamy zpravidla nepřesahuje 30 sekund. Horní hranice 3 minut by měla být spíš orientačním limitem. Doporučuje se nepřekročit 2 minuty, a to ani v případě, že návštěvník má možnost nahrávku přerušit nebo ukončit a přejít na další zastavení. Margot Wallace dokonce předkládá konkrétní strukturu ideálního zastavení. Z nahrávky dlouhé 30 sekund až jednu minutu ( $\mathrm{v}$ anglickém jazyce tomu odpovídá 80 až 150 slov, v češtině o něco méně) by přibližně $20 \%$ měl zabírat úvodní jasný popis předmětu, 60 \% se doporučuje věnovat kontextu předmětu a dalším informacím. Závěrečných 20 \% by mělo být věnováno přemostění $\mathrm{k}$ dalšímu objektu, a to i $u$ verze $s$ možností manuálního navolení následujícího zastavení, jelikož řada návštěvníků i tak preferuje následování doporučené trasy. ${ }^{37}$ 
Bez ohledu na to, jestli se tyto doporučení povede dodržet nebo se autoři trasy spolehnou spíš na svůj vlastní odhad, návštěvník bezesporu ocení, když bude časový údaj o celé délce trasy nebo zastavení dopředu známý. ${ }^{38}$ Mobilní aplikace nebo zařízení s displejem umožní také zobrazení ukazatele času, který zbývá do konce nahrávky nebo prohlídky. Možností je také verbální upozornění například v polovině trasy. Návštěvník tak může rozhodnout o své trase nebo její variantě, přestávkách během prohlídky nebo návštěvě muzejního obchodu nebo kavárny.

At’ jsou už jednotlivá zastavení prohlídkové trasy audio průvodce jakékoliv délky, na udržení pozornosti posluchače se podílí i řada dalších faktorů. Během samotné př́pravy textu jednotlivých zastavení se doporučuje minimalizovat použití dlouhých a neznámých pojmů, v případě, že se tomu nelze vyhnout, tak pojem co nejdřív srozumitelně objasnit. Obecně by měla platit výrazná preference kratších slov, optimálně do 4 slabik. Efektivní je zapojení orientace $\mathrm{v}$ prostoru pomocí častého použití ukazovacích zájmen a formulací. Zejména v případě vícero nabízených variant tras audio průvodce nebo jeho nahrávek je také možné do scénáře začlenit anekdoty, příhody nebo zajímavosti, které rozšiřují základní nabízené informace.

Forma audio průvodce má oproti klasické komentované prohlídce navíc zásadní výhodu v tom, že umožňuje jednoduché zařazení nahrávek do samotného výkladu. Posluchač nepochybně ocení např́iklad krátkou promluvu odborníka na dané téma nebo autora předmětného uměleckého díla (zejména u klíčových exponátů vyžadujících komplexnější výklad a větší délku zastavení). Použití ilustračních zvukových efektů u řady návštěvníků zvyšuje míru zapamatování předmětů nebo částí výstavy, ke které se vztahují. V neposlední řadě je audio průvodce ideální příležitostí k představení zvukových záznamů ze sbírek muzea. Již krátká nahrávka hlasu historické osobnosti bez ohledu na její obsah přenese posluchače do atmosféry předmětného období a upevní pocit autenticity, a to i v př́padě, že předmět samotný autentický není. ${ }^{39}$

\section{Vypravěč}

Se snahou udržet pozornost posluchače a zároveň zatraktivnit poslech audio průvodce úzce souvisí i výběr vypravěče. I v této oblasti se trendy a preference návštěvníků za poslední desetiletí zásadně mění. Standardem býval mužský hlas profesionálního herce nebo dabéra (mužský hlas měli posluchači tendenci vyhodnocovat jako důvěryhodný). V současnosti se u výběru hlasu audio průvodce klade dưraz na celkový smyslový prožitek posluchače, kontextuální nebo emocionální vazbu vypravěče $\mathrm{k}$ výstavě nebo expozici, a nezanedbatelný je i marketingový aspekt audio průvodce. Wallace doporučuje roli svěřit kurátorovi výstavy nebo jinému odborníkovi, jelikož se domnívá, že jejich znalost tématu a zkušenost $s$ jeho prezentací se pozitivně odrazí na plynulosti nahrávky. ${ }^{40}$ Tento prístup ale není pravidlem a řada institucí se snaží spís přiblížit se široké veřejnosti prostřednictvím výběru zavedeného hlasového herce nebo podnítit zájem cílové skupiny spoluprací s mainstreamově známou osobností. Již v 90. letech začala velká americká muzea, jako Americké př́ŕrodovědné muzeum nebo Muzeum moderního umění v New Yorku, spolupracovat na tvorbě audio průvodců s populárními hvězdami stř́brného plátna. ${ }^{41}$ Ve snaze přilákat mladé návštěvníky $\mathrm{v}$ posledních letech muzejní instituce oslovují i oblíbené tváře sociálních platforem jako YouTube nebo TikTok. Zejména v galeriích a muzeích umění je během audio průvodce využívaná i forma dialogu, zpravidla mezi vypravěčem (hlasovým hercem, novinářem) a umělcem, kterého díla jsou předmětem výstavy nebo její části.

Návštěvnicky atraktivním přístupem je také audio průvodce vyprávěn postavou, at' už fiktivní nebo historickou. Tento přístup se přímo nabízí v památkových objektech (vypravěčem může být některý z majitelů objektu, jeho rodina, nebo smyšlená postava se vztahem k místu), ale efektivní může být i v muzeích a galeriích,
38 MANNION, Shelley, SABIESCU, Amalia, ROBINSON, William. An audio state of mind. Understanding behaviour around audio guides and visitor media.

39 Více ke vztahu návštěvníka a autenticity $v$ muzeu napr. ŘEZNÍČKOVÁ, Viera. Vliv autenticity na percepci exponátu. In. Museologia Brunensia, roč. 8, č. 2 (podzim 2019), s. 46-48. 40 WALLACE, Margot. Writing for Museums, s. 6.

41 VOGEL, Carol. Museums Speak in Celebrity Voices. In. New York Times, roč. 146, č. 323 (18. listopad 1996), [cit. 2021-01-20]. Dostupné z: https://www.nytimes. com/1996/11/18/arts/museums-speak-in-celebrity-voices.html. 
42 TALLON, Loic; WALKER, Kevin. Digital Technologies and the Museum Experience: Handheld Guides and Other Media, s. 170-171. 43 Muzeum nové generace [cit. 2021-01-20]. Dostupné z: https://www.zamekzdar.czl muzeum-nove-generacel [cit. 2021-01-20].

44 Stálé expozice muzea v Šumperku [cit. 2021-0120]. Dostupné z: http://www. muzeum-sumperk.cz/domains/ muzeum-sumperk.czlindex. php/cs/expozice/priroda-a-dejiny-severozapadni-moravy. 45 You've built a heritage app. How do you spread the word? Calvium has some tips [online]. In Museums + Heritage, 20. červen 2019 [cit. 18.5.2021].

Dostupné z: https://advisor. museumsandheritage.com/ supplier-news/youve-built-heritage-app-spread-word/. 46 JOHNOVÁ, Radka. Marketing kulturního dědictví a umění. Praha: Grada, 2008,

s. 185.

47 "to reinforce both the experiences the visitor has inside the museum and those outside, before and after the visit." (překl. autorka) FALK, John Howard, DIERKING, Lynn Diane. The Museum Experience. Washington: Whalesback Books, 1992, s. 151. a to nejen u výstav věnovaných konkrétní osobnosti nebo tématu. Vědecké centrum Universeum ve švédském Gothenburgu třeba připravilo dětskou trasu audio průvodce, která je vyprávěna $\mathrm{z}$ pohledu zvírete, které si dítě samo zvolí z nabídky. ${ }^{42}$ Dítě se tak dozví informace o říčním ekosystému (téma expozice) a zároveň je dokáže ihned vztáhnout k vybranému představiteli živočichů $\mathrm{z}$ tohoto prostředí. Z českých institucí se touto cestou vydalo například Muzeum nové generace na zámku ve Žd’áře nad Sázavou, otevřeno v roce 2015, kde expozicí provází hlas cisterciáckého mnicha a holčičky ze současnosti. ${ }^{43}$ Ve Vlastivědném muzeu v Šumperku zase od roku 2008 mohou návštěvníci slyšet vyprávění Paulíny Chiari, manželky nejznámějšího majitele areálu dnešního muzea. Audio průvodce je zde doplněn i o autentické zvuky a dobovou hudbu, což umocňuje prožitek návštěvníka a komunikaci záměru tvůrců trasy. ${ }^{44}$ V případě aplikace této varianty je ovšem důležité mít na paměti rovnováhu mezi oběma funkcemi audio průvodce - vzdělávací a zábavnou. At jsou informace sdělovány jakoukoliv formou, měly by být správné, úplné a zároveň srozumitelné.

\section{Marketing}

Ačkoliv by se mohlo zdát, že finalizací samotného audio průvodce - vytvořením scénáře trasy, nahráním zastavení a technickou realizací - je proces ukončen, není tomu tak. Stejně jako u výstav, doprovodných programů nebo publikací je nevyhnutelnou etapou jeho představení veřejnosti a marketingová kampaň. V ideálním případě lze o audio průvodci informovat veřejnost již před jeho spuštěním (zkušební prohlídka pro novináře nebo zástupce cestovního ruchu) nebo záhy poté (oslovení blogerů, influencerů nebo jiných veřejně známých osob k propagaci). ${ }^{45}$ Návštěvník by již před vstupem do budovy muzea měl vědět o možnosti audio prưvodce, naprríklad prostřednictvím přístupných a snadno vyhledatelných informací na webových stránkách instituce, případně dalších navštěvovaných turistických serverech. Stejně tak by o audio průvodci měl být návštěvník informován hned u vstupu do muzejní budovy, ideálně formou piktogramu nebo jinak srozumitelného a viditelně umístěného upozornění. Stejně přístupné a jasné by měly být i informace o ceně, technické formě nebo nabízených variantách průvodce. Nezbytnost kompetentního personálu v kontaktu s návštěvníky již byla zmíněna.

V současné éře rychlého internetového připojení a rozšířených chytrých telefonů s nespočtem funkcí je marketingově výrazně výhodnější varianta audio průvodce ve formě souborů nebo aplikace ke stažení. Takto může audio průvodce působit jako velmi efektivní propagační produkt; je téměř zaručeno, že zákazník, který si ho stáhne, muzeum určitě navštíví. ${ }^{46}$ Jak uvádí Falk a Dierking v jedné z prvních publikací věnujících se výzkumu návštěvníků, u výstav, doprovodných programů a dalších prvků muzejní komunikace je žádoucí, aby "podpořily a zesílily prožitek návštěvníka uvnitř muzea i mimo něj, před i po návštěvě." 47 Ačkoliv není pochyb o tom, že i audio průvodce $\mathrm{v}$ zapůjčeném zařízení může mít pozitivní vliv na edukativní i zábavní aspekt prohlídky, z hlediska propagace muzea jako produktu je výhodné, pokud má návštěvník nebo zájemce $\mathrm{k}$ němu př́stup i mimo ní. At’ už ve formě "preview" toho, co ho čeká během návštěvy (podobnou funkci mohou mít webové stránky, virtuální výstavy nebo video pozvánky), nebo možností vrátit se $\mathrm{k}$ prožitku z již proběhlé návštěvy, co má potenciál působit motivačně k návratu do instituce. Zejména u muzeí lokálního významu, která necílí primárně na turisty a je pro ně zásadní stabilní místní publikum, může být tato funkce off-line průvodce nebo aplikace zásadní. Stejně jako $v$ případě nyní již hojně rozšírených virtuálních výstav, i zde není namístě obava části muzejních pracovníků, že s poskytnutím digitálního obsahu se sníží motivace lidí k fyzické návštěvě. Žádný z řady průzkumů na toto téma tento předpoklad nepotvrdil, naopak bylo prokázáno, že zájemci o digitální produkty muzeí a galerií patří do skupiny lidí, 
kteří se o kulturu zajímají a aktivně se ji účastní. ${ }^{48}$

Efektivní využití v současnosti běžně použivaných a populárních technologií má vysoký potenciál oslovit zejména cílovou kategorii mladých lidí, u které zájem o muzea a galerie dlouhodobě stagnuje. Volnočasové a společenské aktivity jsou u této skupiny výrazně orientovány na oblast internetu, sociálních sítí nebo rychle rozvíjejících se, adaptabilních a vysoce interaktivních technologií. ${ }^{49}$ Právě jejich efektivní zapojení do muzejního marketingu a komunikace $\mathrm{s}$ veřejností může být klíčové pro tvorbu atraktivního image pro instituci. Právě během uzavření muzeí veřejnosti $\mathrm{z}$ důvodu pandemie se řada institucí pokusila touto cestou zaujmout mladé lidi od školáků po mladé dospělé, včetně reakce na prudce vzrůstající zájem o podcasty, e-booky a další zvukové produkty, které jsou $\mathrm{k}$ dispozici ke stažení v aplikacích nebo na platformách jako Spotify nebo iTunes. Audio průvodce $\mathrm{v}$ některé $\mathrm{z}$ off-line forem proto může $\mathrm{v}$ souvislosti s tímto trendem představit muzeum jako instituci, která kráći s dobou a která je otevřená a srozumitelná mladým generacím.

Dnes i muzea regionálního nebo místního významu musí počítat $s$ tím, že část jejich návštěvníků budou představovat zahraniční turisté. Již u tvorby audio průvodce je proto doporučeno na tuto cílovou skupinu myslet. Zejména turisté ze zemí západní Evropy nebo severní Ameriky považují nabídku audio průvodce $\mathrm{v}$ některém ze světových jazyků (zpravidla $\mathrm{v}$ angličtině) za samozřejmost, a to i v př́padě, že je v nabídce cizojazyčná komentovaná prohlídka s lektorem. ${ }^{50}$ Informaci o této možnosti je proto vhodné uvést na cizojazyčné verzi webových stránek instituce, informačních tabulích $\mathrm{v}$ areálu, prrípadně ji sdělit lokálním informačním a turistickým centrům nebo internetovým portálům. I v tomto př́padě je marketingově více výhodné umístit audio průvodce $\mathrm{k}$ dispozici na webovou stránku nebo do aplikace ke stažení. Mobilní telefon je dnes již téměř nezbytnou pomůckou turistů cestujících za kulturními památkami.
Ačkoliv je možné diskutovat o tom, jestli je vhodnější forma responzivní webové stránky nebo aplikace pro chytrý telefon, výzkumy zcela jasně prokazují preferenci použití vlastního zařízení ve výstavních prostorách i mimo nich. ${ }^{51}$

\section{Audio průvodce pro návštěvníky se zrakovým postižením}

Velkou výhodou využití audio průvodců v muzeu, galerii nebo památkovém objektu je možnost zprostředkování prožitku i pro návštěvníky s omezeným vizuálním vnímáním. Jedním z úkolů těchto institucí je umožnit i lidem se specifickými potřebami plnohodnotný, pohodlný a př́ijemný zážitek $\mathrm{z}$ návštěvy a předat jim klíčové vjemy a informace adekvátní formou. Již dlouho neplatí zažité představy o tom, že lidé se zrakovým postižením nemohou vnímat umění, a tedy nemají ani zájem o návštěvu galerie nebo umělecké výstavy. ${ }^{52}$ Řada muzeí má již v nabídce komentované prohlídky, at' už skupinové nebo individuální, přizpůsobené potřebám jednotlivých skupin návštěvníků s postižením, včetně návštěvníků nevidomých a slabozrakých. Audio průvodce je i v tomto př́padě praktickou alternativou nebo doplňkem - uživatel si může zvolit vlastní tempo, délku nebo obsah prohlídky. Bylo by ale nesprávné domnívat se, že nahrávka určena pro běžného návštěvníka je plně dostačující pro návštěvníka s omezeným zrakovým vnímáním. Standardní formy průvodců - at' už je to textový, zvukový, digitální nebo v osobě lektora - jsou určeny jako doplněk a rozšíření prožitku, který je (až na výjimky v podobě taktilních prvků) primárně vizuální. Pokud návštěvník vizuální vjem částečně nebo kompletně postrádá, jsou pro něj pouze základní informace o předmětu a jeho kontextu zcela nedostačující. Tvorba scénáře audio prohlídky pro návštěvníky se zrakovým omezením se drží stejného postupu, jako příprava scénáře jakékoliv jiné audio nebo komentované prohlídky, s výjimkou některých specifik. Zásadní rozdíl je $\mathrm{v}$ tom, že je nezbytné sdělit informace, které jsou pro vidícího
48 KESNER, Ladislav. Marketing a management muzeí a památek, s. 211. 49 KESNER, Ladislav. Marketing a management muzeí a památek, s. 210. 50 WALLACE, Margot. Writing for Museums, s. 10. 51 McCORMICK, Rosemary Rice. Marketing Cultural \& Heritage Tourism: A World of Opportunity. London, New York: Routledge, 2011, s. 121. 52 Více napr. HAYHOE, Simon. Blind Visitor Experiences at Art Museum. Lanham: Rowman and Littlefield, 2017. 
53 KLEEGE, Georgina. More than Meets the Eye: What Blindness Brings to Art. Oxford: Oxford University Press, 2018, s. 118.

54 BERNARD, Patrick, FABRE, Pierre. Muzea pro všechny: Př́ručka $k$ fyzické a smyslové dostupnosti muzeí. Praha: Český výbor ICOM, AMG ČR, 2003 s. 38.

55 GIANSANTE, Lou. Writing Verbal Description Audio Tours [online] [cit. 18.5.2021]. Dostupné z: http://www. artbeyondsight.org/mei/wp-content/uploads/Writing-forAudio-Guides-short.pdf.

56 GIANSANTE, Lou. Writing Verbal Description Audio

Tours.

57 WALLACE, Margot. Writing for Museums, s. 13. návštěvníka zřejmé nebo které si návštěvník dokáže spojit se známou analogií. Na druhou stranu prŕliš mnoho sdělených informací může stát $\mathrm{v}$ cestě jejich plnohodnotnému vnímání i samotnému prožitku z návštěvy muzea, která má mnoho jiných aspektů kromě těch edukačních. ${ }^{53}$ Stejně jako u standardního komentáře nebo popisku předmětu je vhodné na úvod uvést jeho název, jméno umělce, rok nebo období vzniku a další základní informace. Ačkoliv je žádoucí nabídnout tyto informace $\mathrm{i}$ ve formě popisků nebo letáků v Braillově písmu, je potřeba mít na paměti, že četba $v$ Braillově písmu je náročná na pozornost, a ne všichni lidé se zrakovým znevýhodněním toto písmo číst umí. ${ }^{54} \mathrm{U}$ popisu vizuálního aspektu exponátu je doporučeno uvést i úhel pohledu, který je pro návštěvníka k vidění, a směr, ve kterém bude předmět detailněji popisován. Pokud je to možné, efektivním způsobem sdělení informací o předmětu je použití přirovnání. Sdělení velikostních parametrů je žádoucí, ale standardní jednotky měření jsou př́liš abstraktní. Užitečnější je $\mathrm{v}$ tomto př́ípadě výšku nebo šîrku přirovnat $k$ běžně používaným předmětům - list papíru, dlaň, židle apod. Podobně je možné pojmout i deskripci tvaru předmětu, zejména $v$ př́padě složitých nebo abstraktních linií. Pokud to ale materiál nebo textura předmětu umožňují jen obtížně, možností je blíže charakterizovat techniku použitou u výroby popisovaného exponátu. Vysvětlení, že malîr $\mathrm{v}$ procesu tvorby nanášel hrubou vrstvu barvy širokými tahy, je mnohem srozumitelnější než snaha popsat výsledný efekt. ${ }^{55}$ Pochopitelně je ideální, pokud jsou součástí výstavy haptické modely exponátů zahrnutých ve scénáři audio průvodce, nebo je př́padně možné dotknout se vystaveného exponátu př́mo. Není nutné u popisu vynechávat barvu předmětu řada uživatelů audio průvodce může mít zbytky zraku a tuto informaci ocení, v současnosti také existují mobilní aplikace na rozeznávání barev pro osoby se zrakovým postižením.

$\mathrm{V}$ některých případech navíc vizuální detaily, které se mohou zdát nepř́lišs důležité pro zmínku v audio průvodci pro tuto cílovou skupinu, mohou být zásadní pro pochopení kontextu předmětu, jako použití určitých barev nebo symbolů, rysy obličeje nebo barva pleti poukazující na určitou, pro objekt relevantní etnickou př́slušnost zobrazeného člověka apod. V takovém případě je potřeba mít na mysli, že zatímco vidící návštěvník si tyto detaily automaticky prriřadí $\mathrm{k}$ jejich významu, u absence vizuálního vjemu je nutné věnovat čas jejich objasnění. ${ }^{56}$

Přínosem pro návštěvníka se zrakovým postižením je také popis nejen předmětu samotného, ale také popis způsobu jeho vystavení, designu výstavy a výstavních prostor samotných. Návštěvník získá komplexnější dojem z návštěvy výstavy, pokud bude informován o designu vitríny, způsobu a poloze umístění předmětu, jeho vzdálenosti od dalších vystavěných objektů nebo celkovém záměru konkrétní instalace nebo její části. Zcela specifická oblast, která by neměla být opomenuta jak v scénáŕi audio průvodce, tak i v prípadě komentované prohlídky určené cílové skupině lidí se zrakovým omezením, jsou informace o podobě výstavních prostor samotných a muzejní budově. Velikost místnosti nebo chodeb, materiál podlahy nebo dveří, osvětlení nebo umělecké prvky jsou sdělení, které i pro běžného návštěvníka, který je přijímá zrakem, mají vliv na celkový prožitek $\mathrm{z}$ návštěvy muzea. ${ }^{57}$ Navíc na rozdíl od sbírkových předmětů je zcela v pořádku dotknout se tapet na zdech nebo dekorativního zakončení zábradlí na schodišti. Uživatel audio průvodce může být $\mathrm{k}$ využití dalších smyslů prímo vyzván $\mathrm{v}$ rámce scénáře komentáře. Zaposlouchání se do zvuků návštěvníků ve vstupní hale muzea nebo vdechnutí vůně dřevěného zařízení místnosti mají nejen funkci dokreslování atmosféry a umocňování prožitku, ale nesou také informační hodnotu, která by se slovy dala jen těžce dosáhnout.

Ačkoliv jsou uvedená doporučení určená pro audio průvodce s cílovou skupinou uživatelů se zrakovým postižením, je zejména pro menší muzea nesporně ekonomicky výhodnější limitovat počet 
nabízených komentářů. $\mathrm{V}$ posledních letech proto začíná být trendem trasy audio průvodců pro běžné návštěvníky a pro návštěvníky s omezením zraku nerozlišovat. Kromě zjednodušení procesu tvorby nahrávek a finanční stránky projektu je tak oběma skupinám návštěvníků $\mathrm{k}$ dispozici ta samá prohlídková trasa a informační sdělení. Tím je prohlídka praktičtější pro smíšené skupiny návštěvníků s postižením i bez něj, zejména jelikož zpravidla jsou osoby se zrakovým omezením doprovázeny osobou vidící. Giansante, který ve své praxi autora scénářù audio průvodců tuto metodu upřednostňuje, navíc přizvukuje, že vzniklá atmosféra inkluze a tolerance má potenciál podnítit $\mathrm{k}$ návštěvě širší spektrum návštěvníků i mimo cílovou skupinu instituce. ${ }^{58}$ Zcela ideální je v každém případě tvorbu scénáře audio průvodce konzultovat s návštěvníky nebo pracovníky muzea se zrakovým postižením.

\section{Závěr}

Už od prvního rozšiření přenosných přehrávačů zvuku se $\mathrm{v}$ muzejnictví experimentovalo $\mathrm{s}$ předem nahraným výkladem. Kromě atraktivity, kterou s sebou nesou veškeré nové technologie, se brzy prokázalo, že implementace zvukového průvodce má pozitivní vliv i na prožitek návštěvníků. Možnost vnímání informací sluchem, zvolení vlastního tempa prohlídky nebo variabilita $v$ nabízených trasách a komentárích způsobily, že audio průvodce $\mathrm{v}$ některé ze svých forem je dnes již téměř neoddělitelnou součástí nabídky muzeí a galerií.

S rychlým vývojem digitálních technologií ve všech sférách života se ale zvyšují také nároky na služby poskytované muzei. Zejména rozšíření chytrých telefonů s sebou přineslo nové možnosti digitálního obsahu, který je př́stupný i mimo muzejní budovu, a má tak marketingový nebo edukační potenciál. Nepřeberné množství funkcí v rámci mobilních aplikací umožňuje samotného audio průvodce doplnit textem, multimediálním obsahem, interaktivními prvky nebo propojením se sociálními sítěmi. Chytré telefony již nejsou jen záležitostí mladých lidí, naopak mobilní aplikace muzeí se díky svému širokému potenciálu stávají v zahraničí samozřejmostí.

Pochopitelně vzhledem k různorodému zaměření, cílové skupině, finančním možnostem nebo marketingové strategii muzejních institucí není možné připravit jednoznačné doporučení ohledně využívání, formy nebo scénáře audio prưvodců. Stejně jako v ostatních sférách muzejního provozu je nezbytná spolupráce mezi jednotlivými odborníky a odděleními, sledování současných trendů a zpětné vazby návštěvníků. $V$ neposledním řadě je nezbytné mít na zřeteli také návštěvníky se smyslovými, fyzickými nebo jinými omezeními, kteří mají také zájem získat plnohodnotný zážitek z návštěvy muzea, přizpůsoben jejich požadavkům a potřebám.

\section{Seznam literatury}

AMBROSE, Timothy; PAINE, Crispin. Museum Basics: The International Handbook. London, New York: Routledge, 2018.

BERNARD, Patrick, FABRE, Pierre. Muzea pro všechny: Příručka $k$ fyzické a smyslové dostupnosti muzeí. Praha: Český výbor ICOM, AMG ČR, 2003.

BEST, Katie. Making Museum Tours Better: Understanding What a Guided Tour Really Is And What A Tour Guide Really Does. In Museum Management and Curatorship, roč. 27, č. 1 (únor 2012), s. 35-52.

BORG, James. Umění presvědčivé komunikace. Praha: Grada, 2007.

CHARR, Manuel. What Can Near-Field Communications Do For Museums? In. MuseumNext, 13. záŕí 2019 [cit. 2021-0120]. Dostupné z: https://www.museumnext.com/article/what-can-near-field-communications-do-for-museums/.

COATES, Charlotte. How Museums are using Augmented Reality. In. MuseumNext, 17. záŕí 2020 [cit. 2021-01-20]. Dostupné z: https://www.museumnext.com/article/ how-museums-are-using-augmentedreality/.
58 GIANSANTE, Lou. Writing Verbal Description Audio Tours. 
DOUŠA, Pavel. Text ve výstavě. In Múzeum, roč. 54, č. 1 (2008), s. 11-13.

FALK, John Howard, DIERKING, Lynn Diane. The Museum Experience. Washington: Whalesback Books, 1992.

GIANSANTE, Lou. Writing Verbal Description Audio Tours [online] [cit. 18.5.2021]. Dostupné z: http://www.artbeyondsight.org/mei/wp-content/uploads/ Writing-for-Audio-Guides-short.pdf.

HAYHOE, Simon. Blind Visitor Experiences at Art Museum. Lanham: Rowman and Littlefield, 2017.

HEIMBROCK, Anna. Corona-proofing museum interactives. In. MuseumNext, 10. srpen 2020 [cit. 2021-01-20]. Dostupné z: https://www.museumnext.com/article/ corona-proofing-museum-interactives/.

HUGHES, Philip. Exhibition Design. Londýn: Laurence King, 2010.

JOHNOVÁ, Radka. Marketing kulturního dědictví a umění. Praha: Grada, 2008.

KESNER, Ladislav. Marketing a management muzeí a památek. Praha: Grada, 2005. KLEEGE, Georgina. More than Meets the Eye: What Blindness Brings to Art. Oxford: Oxford University Press, 2018.

KOCICHOVÁ, Ivana. Výstava Pravěk Československa (1958) v Národním muzeu: Světlo, zvuk a pohyb v roli průvodce návštěvníka. In. Muzeum: Muzejní a vlastivědná práce, roč. 53, č. 2 (2015), s. 11-16. KUBŮ, Nad'a, KADLEC, Miloš, FAMĚROVÁ, Dagmar, HOLUB, Jiří, WAGNER, Peter. Metodika průvodcovské činnosti na hradech, zámcích a dalšich zpřístupněných památkách. Praha: Národní památkový ústav, 2014.

LLOYD, Sandra M., SCHREIBER, Susan

P. Great Tours!: Thematic Tours and Guide Training for Historic Sites. Lanham: Altamira Press, 2001.

MANN, Laura, TUNG, Grace. A new look at an old friend: Reevaluating the Met's audio-guide service [online]. MW2015: Museums and the Web 2015 [cit. 25.6.2021]. Dostupné z: https://mw2015.museumsand theweb. com/paper/a-new-look-at-an-old-friend-re-evaluating-the-mets-audio-guide-service/.

MANNION,Shelley, SABIESCU, Amalia, ROBINSON, William. An audio state of mind. Understanding behaviour around audio guides and visitor media [online]. MW2015: Museums and the Web 2015 [cit. 25.6.2021]. Dostupné z: https://mw2015.museumsandtheweb.com/paper/an-audio-state-of-mind-understanding-behviour-around-audio-guides-and-visitor-media/.

MARQUES, Diana, COSTELLO, Robert. Reinventing Object Experiences with Technology. In. Exhibition, roč. 37, č. 1 (jaro 2018), s. 81.

Muzeum nové generace [cit. 2021-01-20]. Dostupné z: https://www.zamekzdar.cz/ muzeum-nove-generace/ [cit. 2021-01-20]. ŘEZNÍČKOVÁ, Viera. Vliv autenticity na percepci exponátu. In. Museologia Brunensia, roč. 8, č. 2 (podzim 2019), s. $46-48$.

Stálé expozice muzea v Šumperku [cit. 2021-01-20]. Dostupné z: http://www. muzeum-sumperk.cz/domains/muzeum-sumperk.cz/index.php/cs/expozice/ priroda-a-dejiny-severozapadni-moravy. TALLON, Loic; WALKER, Kevin. Digital Technologies and the Museum Experience: Handheld Guides and Other Media. Plymouth: AltaMira Press, 2008.

VERGO, Peter (ed.). New Museology. London: Reaktion Books, 1989.

VELÁZQUEZ MARRONI, Cynthia. Beyond the „object-oriented vs. visitor/ idea-oriented museum" divide: the value of objects for museum experiences. In Museologica Brunensia, roč. 6, č. 1 (2017), s. 12-21.

VOGEL, Carol. Museums Speak in Celebrity Voices. In. New York Times, roč. 146, č. 323 (18. listopad 1996), [cit. 202101-20]. Dostupné z: https://www.nytimes. com/1996/11/18/arts/museums-speak-in-celebrity-voices.html.

WAIDACHER, Friedrich. Príručka všeobecnej muzeológie. Bratislava: Slovenské národné múzeum, 1999.

WALLACE, Margot. Museum Branding. How to Create and Maintain Image, Loyalty, and Support. London: Rowman \& Littlefield, 2016.

WALLACE, Margot. Writing for Museums. Lanham: Rowman \& Littlefield, 2014.

What's next for Museum Audio Guides. Research Report / September 2020 [online]. 
Dostupné z: https://www.museumnext. has some tips [online]. In Museums + com/wp-content/uploads/2020/09/muse- Heritage, 20. červen 2019 [cit. 18.5.2021]. ummate_research_report-1.pdf.

You've built a heritage app. How do you spread the word? Calvium Dostupné z: https://advisor.museumsandheritage.com/supplier-news/ youve-built-heritage-app-spread-word/. 